\title{
A rare cause of ileus: late jejunal stricture following blunt abdominal trauma
}

\author{
Ulaş Aday, M.D., ${ }^{1}$ Ebubekir Gündeş, M.D., ${ }^{1}$ Kamuran Cumhur Değer, M.D., ${ }^{1}$ \\ Hüseyin Çiyiltepe, M.D., ${ }^{1}$ Şükran Kayıpmaz, M.D., ${ }^{2}$ Mustafa Duman, M.D. ${ }^{1}$
}

${ }^{1}$ Department of Gastrointestinal Surgery, Kartal Koşuyolu Yüksek İhtisas Training and Research Hospital, İstanbul-Turkey

${ }^{2}$ Department of Patology, Kartal Dr. Lütfi Kırdar Training and Research Hospital, İstanbul-Turkey

\section{ABSTRACT}

Small intestinal stricture forming in the late phase following nonpenetrating abdominal trauma is rare cause of ileus. It has often been suggested that it is result of localized feeding deficiency on the intestinal wall related to minor trauma in the mesentery. Laparoscopy has been increasingly used for diagnosis and treatment. Diagnosis should be supported by pathological analyses in case of intestinal stenosis related to blunt abdominal traumas.

Keywords: Intestinal stenosis; laparoscopy; trauma.

\section{INTRODUCTION}

Small intestinal obstruction forming in the late phase following blunt abdominal trauma is quite rare; studies have reported rate as $1 \%{ }^{[1,2]}$ It is often caused by fibrotic scar formation and blockage of passage entry during healing process of ischemic areas, which develop as result of localized damage to the intestinal wall or the mesentery. ${ }^{[1-4]}$ A 37-year-old male patient, who had occupational accident 2 years prior, was surgically treated at our clinic after presenting with occasional abdominal pain and swelling that had been going on for a year. Presently described is rarely seen case of patient diagnosed with post-traumatic jejunal stricture.

\section{CASE REPORT}

A 37-year-old male patient presented at the clinic with complaints of occasional abdominal pain and distension that had been going on for a year. The patient's history revealed that

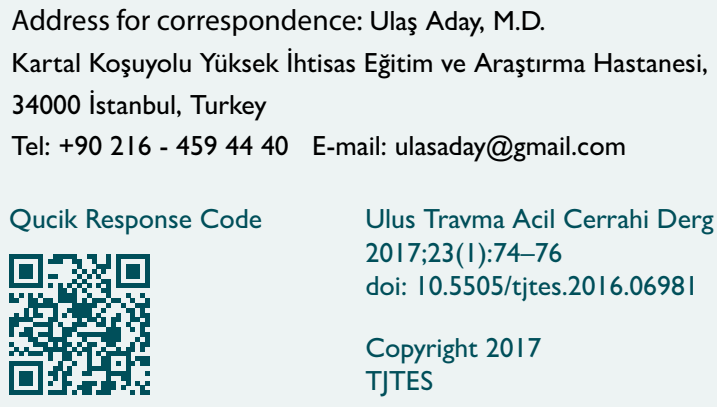

he had previously been treated at another clinic for left iliac wing fracture following a fall from a tractor and that he had been discharged without surgical procedure. His physical examination revealed distended abdomen, increase in intestinal sounds and tympanism in the left upper quadrant, and mild sensitivity. He had linear scar tissue $10 \mathrm{~cm}$ in length on the left iliac wing as result of the traumatic skin laceration. The patient had no known chronic disease or earlier history of surgery. Standing abdominal computed tomography indicated dilated loops of small bowel segments. The patient's hemoglobin level was $9.6 \mathrm{~g} / \mathrm{dL}$ (normal range: $11.1-17.1 \mathrm{~g} / \mathrm{dL}$ ), hematocrit volume was $29.9 \%$ (normal range: $33-54 \%$ ), albumin level was $3.2 \mathrm{~g} / \mathrm{dL}$ (normal range: $3.5-5.2 \mathrm{~g} / \mathrm{dL}$ ), and C-reactive protein level was $4.74 \mathrm{mg} / \mathrm{dL}$ (normal range $0-0.34 \mathrm{mg} / \mathrm{dL}$ ). His other laboratory parameters were within normal limits. Oral and intravenous contrasted abdominopelvic tomography revealed dilated jejunal loops and obstructed area with partial passage at the end point of dilatation. There was also thickening and irregularity in the mesentery of the same segment (Figure I). Nasogastric tube was inserted and medical observation was initiated; however, upon seeing no development in his clinical condition, laparoscopic exploration was performed. Fibrotic thickening was seen in the mesentery of the jejunal segment about $80 \mathrm{~cm}$ from the ligament of Treitz, and circular fibrotic area of $\mathrm{I} \mathrm{cm}$ diameter was observed on the intestinal wall. It was also seen that the proximal segment was quite dilated. Laparoscopic segmental resection and side-to-side jejunojejunal anastomosis were performed. Macroscopic evaluation of the resected portion revealed circular cicatricial area causing narrowness, fibrotic thickening in the mesentery, and dila- 


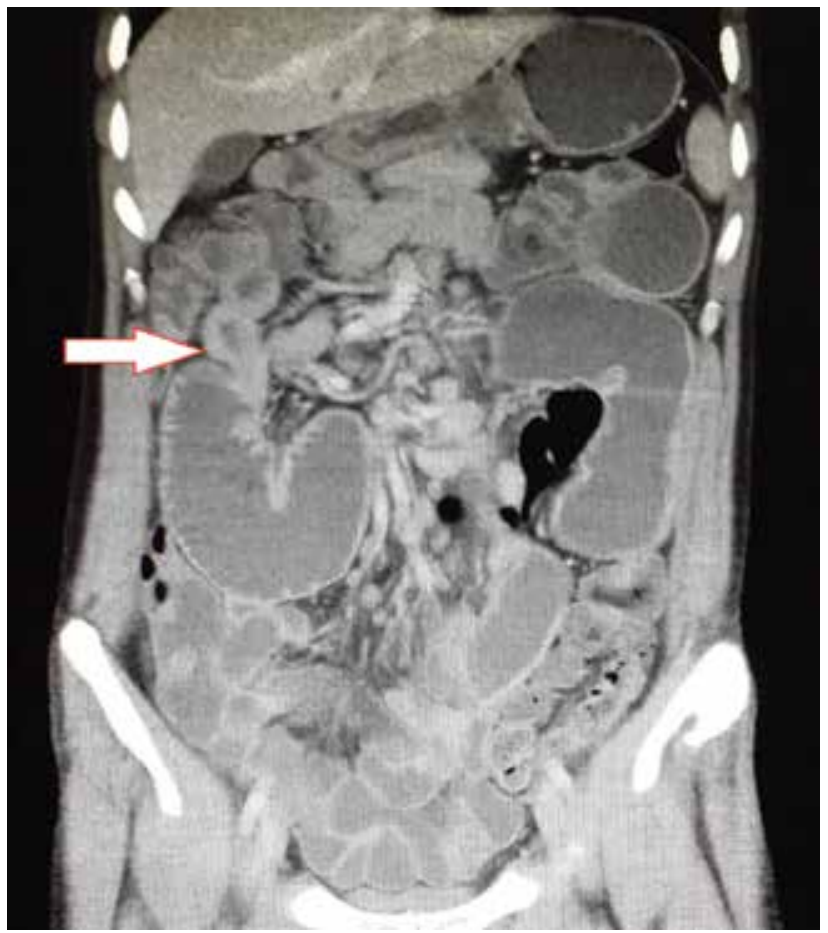

Figure 1. Abdominal tomography section with oral and intravenous contrast.

tation and edema in the proximal loop. It was also observed that distal crossing diameter was quite narrowed (Figure 2). The patient was discharged on post-operative day 8 without any problems. Pathological analysis demonstrated focal ulcerated area and active chronic nonspecific inflammation of the site (Figure 3).

\section{DISCUSSION}

lleus related to post-traumatic intestinal stenosis is rare; studies have reported that rate is about $1 \%^{\left[{ }^{[1,2]}\right.}$ Jejunal stricture related to blunt abdominal trauma often form as result of minor trauma to the mesentery or the intestinal wall. There may be no symptoms that can be seen in the clinical condition of the patient in the early phase. ${ }^{[1,3]}$ Small laceration, hematoma in the mesentery, or contusion and mural hematoma on the intestinal wall give way to localized ischemia. Inadequate mucosal feeding causes bacterial translocation, and ulcer formation and inflammation during tissue healing result in fibrosis and scarring. Authors agree that feeding deficiency related to damaged mesentery is primary reason for stricture formation. ${ }^{[4-6]}$ In the present case, macroscopic evaluation showed fibrotic thickening in the mesentery of the strictured segment. It was suggested that the damage to the mesentery was the principal reason for the patient's condition as pathological analysis revealed focal ulcerated area and active chronic nonspecific inflammation in the area.

Although post-traumatic symptoms are frequently seen 5 weeks after the trauma, there are also reports present-

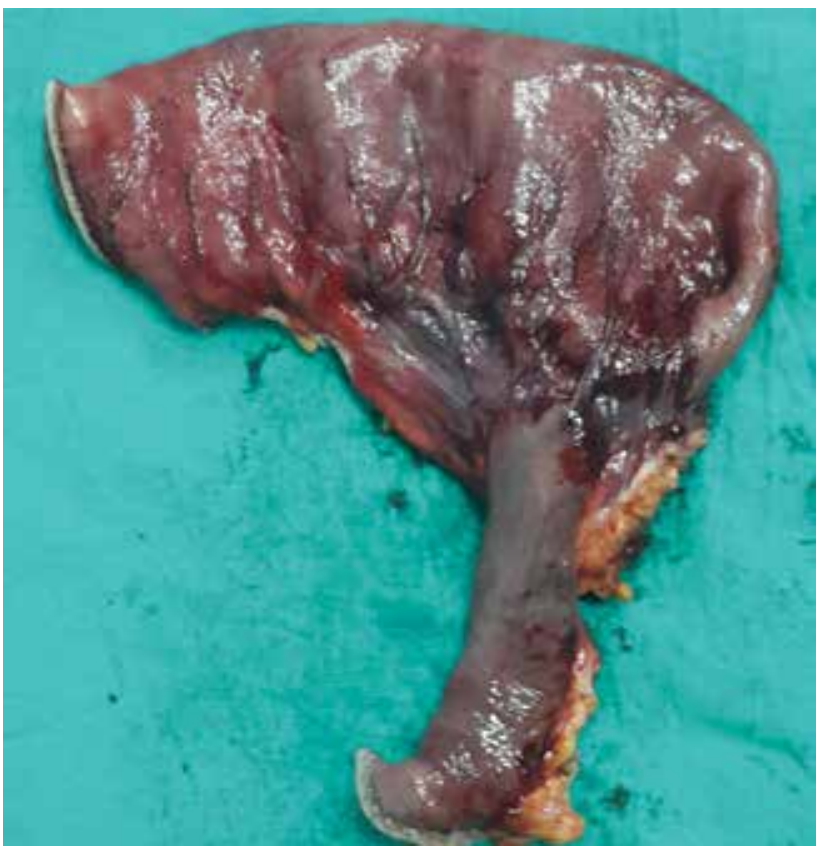

Figure 2. Image of the resected portion.

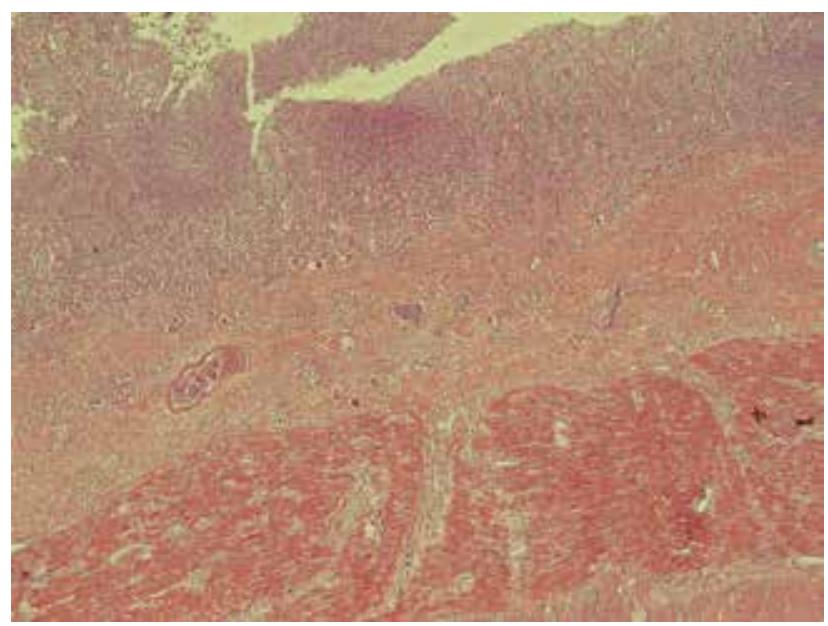

Figure 3. Low-power view of the ulcer illustrates the depth of the lesion and intense mixed-type inflammation (hematoxylin and eo$\sin , x 40)$.

ing cases that remained asymptomatic for a long time..$^{[2-4]}$ In our case, the patient's complaints started a year after the traumatic incident. Symptoms related to partial small bowel obstruction, such as intermittent abdominal pain, distension, nausea, and vomiting are seen. ${ }^{[4,6]}$ Rate of proximal jejunal stricture reported in the literature varies; however, Konobu et al. provided rate of $17.9 \%$ in their study. ${ }^{[4,7]}$

Diagnostic criteria for the condition are as follows: a) previous history of blunt abdominal trauma, b) absence of described pathology before trauma, c) start of symptoms after trauma, d) radiological detection of intestinal stenosis, e) malignity or signs of specific inflammatory diseases seen in pathological evaluation of the resected portion..$^{[1,2,7]}$ Pathological confirmation is significant for cases in which no differential diagnosis 
can be reached through radiological evaluation, and for differentiating cases of Crohn's disease, intestinal tuberculosis, radiation enteritis, or cancer. ${ }^{[1,2,7,8]}$

There has been increase in laparoscopic surgery as result of technological developments and accumulated experience with laparoscopic procedures. Small intestinal obstruction related to adhesion occurs far less often in intra-abdominal laparoscopic procedure in comparison with open surgery. Studies with large scope have demonstrated that laparoscopic treatment has low morbidity and mortality rates for adhesions, which are the most common reason for small bowel obstruction. ${ }^{[8,9]}$ Adhesions requiring re-operation formed within 30 years in $29 \%$ of cases of laparoscopic adhesiolysis. ${ }^{[9,10]}$ In our case, trauma-related stenosis was not initially thought of in the preoperative period. Macroscopic results cast doubt on the diagnostic laparoscopy and the patient was diagnosed based on pathological evaluation. Less invasive laparoscopy to complete the surgical procedure decreased risk of adhesions forming later.

Intestinal stenosis in the late phase related to blunt abdominal trauma is a rare cause of ileus in surgical practice. Resection of the segment causing stricture not only achieves treatment, but also enables histopathological confirmation. Increased surgical experience with laparoscopic procedures has facilitated safe resection of pathological segment and thereby decreased rate of post-operative adhesion formation.
Conflict of interest: None declared.

\section{REFERENCES}

1. Kang GH, Jeon TJ, Seo DD, Oh TH, Kim SH, Cho HS, et al. Ileal stenosis occurred 3 months after blunt abdominal trauma. Korean J Gastroenterol 2011;57:370-3. Crossre

2. Kaban G, Somani RA, Carter J. Delayed presentation of small bowel injury after blunt abdominal trauma: case report. J Trauma 2004;56:11445. Crossret

3. De Backer AI, De Schepper AM, Vaneerdeweg W, Pelckmans P. Intestinal stenosis from mesenteric injury after blunt abdominal trauma. Eur Radiol 1999;9:1429-31. Crossre.

4. Jones VS, Soundappan SV, Cohen RC, Pitkin J, La Hei ER, Martin HC, et al. Posttraumatic small bowel obstruction in children. J Pediatr Surg 2007; 42:1386-8. Crossret

5. Loberant N, Szvalb S, Herskovits M, Cohen I, Salamon V. Posttraumatic intestinal stenosis: radiographic and sonographic appearance. Eur Radiol 1997;7:524-6. Crossre]

6. Maharaj D, Perry A, Ramdass M, Naraynsingh V. Late small bowel obstruction after blunt abdominal trauma Postgrad Med J 2003;79:57-8.

7. Konobu T, Murao Y, Miyamoto S, Nakamura T, Imanishi M, Ueda S, et al. Posttraumatic intestinal stenosis presenting as a perforation: report of a case. Surg Today 1999;29:564-7. Crossret

8. O'Connor DB, Winter DC. The role of laparoscopy in the management of acute small-bowel obstruction: a review of over 2,000 cases. Surg En$\operatorname{dosc} 2012 ; 26: 12-7$. Crossre

9. Ghosheh B, Salameh JR. Laparoscopic approach to acute small bowel obstruction: review of 1061 cases. Surg Endosc 2007;21:1945-9. Crossre

10. Gutt CN, Oniu T, Schemmer P, Mehrabi A, Büchler MW. Fewer adhesions induced by laparoscopic surgery? Surg Endosc 2004;18:898-906.

\section{OLGU SUNUMU - ÖZET}

\section{Nadirgörülen ileus nedeni:Künt karın travması sonrasıgeç dönem gelişen jejunal striktür \\ Dr. Ulaş Aday, ${ }^{1}$ Dr. Ebubekir Gündeş, ${ }^{1}$ Dr. Kamuran Cumhur Değer, ${ }^{1}$ Dr. Hüseyin Çiyiltepe, ${ }^{1}$ \\ Dr. Şükran Kayıpmaz, ${ }^{2}$ Dr. Mustafa Duman ${ }^{1}$}

${ }^{1}$ Kartal Koşuyolu Yüksek İhtisas Eğitim ve Araştırma Hastanesi, Gastroenteroloji Cerrahisi Kliniği, İstanbul

${ }^{2}$ Kartal Dr. Lütfi Kırdar Eğitim ve Araştırma Hastanesi, Patoloji Bölümü, İstanbul

Penetran olmayan karın travmalarına bağlı geç dönemde oluşan ince bağırsak striktürü nadir ileus nedenidir. Sıklıkla mezenterde oluşan minör travmaya bağlı bağırsak duvarındaki lokalize beslenme bozukluğunun sonucu olduğu düşünülmektedir. Laparoskopi tanı ve tedavi uygulamalarında artan oranlarda uygulanmaktadır. Künt karın travmasına bağı intestinal stenozlarda tanının patolojik değerlendirme ile desteklenmesi gerekir.

Anahtar sözcükler: İntestinal stenoz; laparoskopi; travma.

Ulus Travma Acil Cerrahi Derg 2017;23(I):74-76 doi: 10.5505/tjtes.2016.0698। 